\title{
"Sin yo haberlo buscado": Manuel Puig y el Teatro
}

\author{
"Without me having looked for it": Manuel Puig and the theater
}

Laura Conde condelauragabriela@gmail.com

Universidad Nacional de La Plata - CONICET, Argentina

Cita sugerida: Conde, L. (2020). "Sin yo haberlo buscado": Manuel Puig y el Teatro. Orbis Tertius, 25(30), e176. https://doi.org/10.24215/18517811e176

\begin{abstract}
Resumen: El teatro, espacio de cruce entre géneros, formatos y poéticas, es un resto que parece estar desde siempre en la escritura de Puig, y sube a escena en tanto señal corpórea del exilio. Leeremos las didascalias en guiones y textos dramáticos como huella que condensa esos desplazamientos entre cine, teatro y literatura; juntura que expone la inminencia de la pérdida y la transformación, así como el cruce de materialidades, medios expresivos y modos de representar que atraviesan toda la producción de Puig: un problema de traducción-transposición inscripto en una voz que goza simultáneamente de su consistencia y de su caída.
\end{abstract}

Palabras clave: Didascalias, Teatro, Cine, Transposición, Huella.

\begin{abstract}
The theater, a space where genres, formats and poetics intersect, is a remnant that seems to have always been in Puig's writing, and comes on stage as a corporeal sign of exile. We will read the didascalias in scripts and dramatic texts as a trace that condenses those displacements between cinema, theater and literatura; juncture that exposes the imminence of loss and transformation, as well as the intersection of materialities, expressive means and modes of representation, that run through Puig's entire production: a translation-transposition problem inscribed in a voice that rejoices in simultaneously its consistency and its fall.
\end{abstract}

Keywords: Didascalias, Theater, Cinema, Transposition, Trace.

\section{1. “...Y ASÍ FUE QUE EMPECÉ A ESCRIBIR TEATRO”}

El teatro de Manuel Puig ha sido acompañado por un fiel partenaire: el exilio, que inicia en 1974. Paralelamente el sistema teatral argentino atravesaba un período de crisis por el impacto del contexto sociopolítico represivo. Dentro de las producciones de la época, bastante ceñidas a la escenificación de la violencia, existen algunas más poéticas y creativas que otras, o permeables a nuevas formas provenientes del contacto con las vanguardias. El neogrotesco, cuya rearticulación de textualidades previas no estaba exenta de rupturas, el realismo reflexivo de Halac, Cossa, Somigliana, Rozenmacher, el absurdismo de Pavlovsky y Gambaro, la crueldad y distanciamiento experimental de Monti, produjeron un gran cambio en el campo teatral respecto del realismo mensajista de entonces, acentuando a la vez la crítica al régimen dictatorial que desde fines de la década del 60 cercenaba las intervenciones de intelectuales en el ámbito público. En 1981 "Teatro Abierto" intentó resquebrajar el discurso autoritario a través de la presentación de veintiún espectáculos de autores 
nacionales. Puig no participó de estas experiencias, su teatro fue del exilio y, siguiendo a Dubatti, "exiliado", pues no tuvo recepción inmediata en su país y fue apenas reconocido por la crítica posteriormente, frente a la vasta recepción que obtuvo en los escenarios extranjeros. La ausencia de su nombre en los principales libros de historia teatral del período también da cuenta de este "olvido" (Puig, 2011, p. 13).

Si bien Puig escribió comedias musicales y obras de teatro entre 1974 y 1988, en los guiones cinematográficos previos y contemporáneos a esas fechas, así como en su narrativa, también se puede leer la huella de cierto impulso teatral. No registra una escena primera de deslumbramiento por el teatro, como le sucede a Barthes con Brecht, sino que pasa del cine a la literatura y de la literatura al teatro de manera inadvertida, sin proponérselo, siguiendo la lógica del "accidente de las treinta páginas de banalidades" que "sucedió un día de marzo de 1962" (Puig 1985, p. 4). ${ }^{1}$ Este mito que él mismo forja acerca de su entrada a la literatura con La traición de Rita Hayworth (LTRH, 1968), gira en torno del registro por escrito de la voz de la tía para introducir, en off, la escena de un eventual guion que "inevitablemente se volvió novela” (p. 6). En este trayecto descubre que ha compuesto una suerte de monólogo interior, mucho más literario que cinematográfico. Así como por el azar de un recuerdo involuntario la literatura viene al encuentro de Puig, lo teatral parece estar desde siempre como un resto que se manifiesta y lucha por subir a escena. Ya en sus primeros guiones (Amícola, 1996) se advierten, además de una notable profusión de didascalias, las distintas modalidades de estas inscripciones propias del texto dramático que el autor explora. Estas notas que interrumpen el discurso ("entre" el texto y la puesta en escena, o la realización visual e interrupción intratextual que corta el curso del diálogo) y suelen considerarse marginales nos permiten, sin embargo, reflexionar sobre la escritura de Puig, tanto dramática como narrativa; acaso porque son la marca más radical de escritura, si las contrastamos con el texto escrito para ser dicho en el teatro y el cine. Es a partir del análisis de los mecanismos de escritura y los procesos de desubjetivación que se juegan en las didascalias donde es posible pensar, por mencionar un caso paradigmático, esa voz en tercera persona que irrumpe entre (y articula) las cartas, fragmentos de periódico y otros registros, en la novela Boquitas pintadas (1969). Proponemos entonces que lo didascálico es la figura ambigua por excelencia que condensa tanto los desplazamientos entre literatura, cine, y teatro, como la ambivalencia que identifica la escritura de Puig. Además -y no menos relevanteporque allí se expone el problema de la traducción-transposición que atraviesa la producción de Puig; esto es, donde la inminencia de la pérdida (lo no dicho en escena ni ante la cámara) y la transformación o el cruce de materialidades, medios expresivos y modos de representar, se vuelven procedimiento. Un punctum en el que se registran distintas modulaciones de una voz que goza simultáneamente de su consistencia y de su caída. Retomando al Lacan de Barthes: "el goce como tal está interdicto a quien habla, o más aún, (...) no puede ser dicho sino entre líneas” (Barthes, 2008, p. 31). Quizá una parte importante de la singularidad de la escritura de Puig esté ahí, "entre líneas”; no porque haya algo que descifrar (muy por el contrario, todo está expuesto, a veces de manera escandalosa), sino por el carácter productivo de ese sitio de articulación y transformación.

No sería novedoso pensar la potencialidad teatral de ciertos procedimientos de la narrativa de Puig. Es cierto que su producción dramatúrgica coincide con una etapa creativa en la que el diálogo resulta un recurso predominante, junto a la representación de espacios interiores pequeños, tiempos breves, y pocos personajes. Estos rasgos que suelen identificarse con el género dramático y que están presentes especialmente en las novelas publicadas entre 1976 y 1988, son los que frecuentemente se declaran como el motor principal que ha conducido a distintos artistas (y al propio Puig) a realizar transposiciones teatrales y cinematográficas de su narrativa. Pero más que seguir ese trayecto o el de la identificación del primer contacto con lo teatral a partir del ejercicio de "adaptación” -el mito que Puig creó acerca de su inicio en la dramaturgia-, nos interesa delinear el relato de una erótica teatral desde la perspectiva del acontecimiento de su escritura: el teatro no como una zona especialmente erógena para el autor, sino aquello que viene a su encuentro por el goce que promete su intermitencia, en tanto espacio de cruce entre géneros, formatos, y poéticas. Puig registra lo que escucha, recuerda, observa fotos, ve películas, lee, escucha radioteatro y, entonces, escribe, transcribe, diagrama; ${ }^{2}$ pero no captura con la misma intensidad la integridad de un registro o medio expresivo, y salta 
impunemente las descripciones o explicaciones. Así sus textos dramáticos y, especialmente, la ambivalencia de sus didascalias, o bien siguen la tradición de la dramaturgia, porque así lo ha leído -de manera asistemáticay se le impone, o bien la desarticulan al incorporar elementos provenientes de la narrativa y del guion cinematográfico, sin mayores sobresaltos ni advertencias. Como propone Alberto Giordano respecto de la historia de los comienzos de Puig en la literatura, antes que pensar la historia de una "entrada a" la dramaturgia, de una "integración" de lo teatral en lo literario o viceversa, ensayaremos una lectura sensible a "las transformaciones que se producen a partir del intervalo (...) entre el lugar de salida de Puig (lo que está fuera de la literatura) y el lugar de llegada (su lugar en el interior de la literatura)" (1996, p. 4); un "devenir no literario de la literatura" (p. 6), no teatral del teatro, no cinematográfico del cine o, mejor, no previsto por los usos convencionales. Es fundamentalmente en este gesto que se lee la huella de lo teatral y de la puesta en escena: arte contingente, siempre cambiante, constituido en sí mismo por la síntesis de diversas artes (arquitectura, artes visuales, artes sonoras y literatura (Szuchmacher, 2015)). La escritura de Puig experimenta un estado de pérdida a la vez que hace vacilar ciertas congruencias culturales e institucionalizadas de la lectura, en eso que se cuela de otra parte y por azar.

Graciela Goldchluk señala que El desencuentro (título original del proyecto) deviene en $L T R H$, y la voz monologada del protocapítulo inicial que se publica como "Pájaros en la cabeza", luego desaparece o se disemina en una constelación de voces (Puig, 2004, pp.7 y 9). A la voz de la tía que "sólo tenía banalidades para contar" -afirma Puig-, "No hubo modo de hacerla callar (1985, p. 4). Es preciso atender que esta voz alienada que luego calla se dispersa, reaparece junto a otras voces en la novela Cae la noche tropical (1988), y describe un mecanismo de producción, "invade la voz administrada de las acotaciones de los guiones" (Goldchluk, 1996, p. 470). Si lo literario se inaugura en la fuga didascálica, en el intervalo donde irrumpe esa voz fuera de control, es precisamente gracias a su carácter suplementario, prescindible y, por ello mismo, estructural.

Una pieza como Bajo un manto de estrellas (BME, 1982) escrita para ser puesta en escena y, posiblemente, para ser publicada/leída, presenta didascalias tan narrativas como poéticas. Se filtra en esa voz una suerte de narrador que, más que controlar la escena, genera efectos de sentido (irrealidad, alucinación) articulados por la fórmula "como si". La ambivalencia de estas notas se desplaza desde una modalidad de comentario que aclara, explica, subtitula, en la forma tradicional de la "indicación", a otra modalidad poética, digresiva, que preserva la ambigüedad de este texto notablemente estilizado. La certeza que acaso arroja su indeterminación es que el carácter tropológico que la constituye no puede ser atendido desde un abordaje semiótico y pragmático. Esto es claro con la lectura de Mora, que intenta "probar la centralidad de la acotación en la comprensión del texto total" (1988, p. 224). La fuerza pragmática de este "hablante básico" reside en su "confiabilidad" para distinguir entre la verdad y la mentira de cada situación. Tal presupuesto tambalea cuando se confronta con lo que acontece en estas didascalias: un trabajo de "experimentación" que emplea el disfraz, el cliché, el pastiche, la parodia, y nunca calza en ningún género o registro. No obstante, frente a las rupturas que detecta, y cayendo en la trampa fenomenista que tienden las didascalias, Mora insiste en que - “representando al autor" - "no cumplen su función de manera adecuada" sino que obstruyen "una buena comunicación” y dejan la impresión de "intrascendencia o de gratuita confusión” (p. 231). Es que la clave está allí: gratuidad y ambigüedad. Pues no se trata de "la voz del autor" sino de una tercera persona (escritura en grado cero y en constante diferimiento) articulada por el complejo temporal que va de la escritura a la escena, y/o de la escena a la escritura: las huellas provenientes de los procesos de ensayos, estrenos, como marcas materiales en los textos; o la incisión producida por la potencia de visión y el deseo, siempre fantasmáticos. El espesor teórico del trabajo de subtitulado, traducción ${ }^{3}$ y transposición en Puig, gravita justamente en una lógica de este tenor: una deriva sin origen, entre la excedencia, el suplemento y la transformación. En toda la producción de Puig se manifiesta la huella de eso que resulta intraducible de una lengua a otra, de un sistema o medio expresivo a otro. Si no está la puesta -y es poco frecuente encontrarse con obras publicadas que nunca se montaron, como el caso de los musicales Amor del bueno (1974) y Muy señor mio (1975)-, el texto sigue ahí para leerlo con todas las señales de lo espectacular: la "hipótesis de representación" o la presunción de la 
materialidad del hecho escénico (Szuchmacher, 2015). Lo didascálico es el palimpsesto de estos movimientos en la escritura de Puig que, siempre a punto de perderse, dramatiza el riesgo de lo escrito. No constituye un archivo acabado sino un permanente estado de archivación (Derrida, 2013): escribe, corrige, y transforma, entre pretextos y obras publicadas, textos literarios y realizaciones escénicas o cinematográficas. ${ }^{4}$

\section{INTERMITENCIAS DE UN AMOR (DEL BUENO)}

Como se observó más arriba, la producción dramática de Puig tuvo lugar por fuera del sistema teatral argentino contemporáneo. Dubatti encuentra, no obstante, algunas coincidencias entre Visita, de Ricardo Monti, "extraña pieza" estrenada en 1977 (Puig, 2011, p. 13), y Bajo un manto de estrellas (1983). Ciertamente ambas tienen en común lo que Jorge Monteleone (1987) destaca acerca de Visita: la familia como espacio simbólico polisémico, espacios cerrados como sitio imaginario que concentra el mundo exterior que se condena, juegos rituales y máscaras. Pero la coincidencia probablemente se deba más a una experiencia común de época, entre otros aspectos que sin duda sería interesante indagar, que a la participación directa de Puig en las discusiones teatrales del momento. Antes de su exilio en México, Nueva York y Río de Janeiro, Puig había viajado para estudiar y trabajar en cine (Roma, Londres, París); y se formó en idiomas (inglés, francés, italiano y alemán). Si bien no hay un destino sino un tránsito constante, quizás el teatro (además del cine) sea el sitio huésped que aloja su escritura: las producciones dramatúrgicas y cinematográficas, en español y en otras lenguas, superan en cantidad a las narrativas, entre 1974 y 1988. Ante este dato objetivo se alzan las siguientes preguntas: ¿Cómo hacer contacto directo con un público nuevo? ¿Cómo hacerse un lugar? No hay textualidad más recortada a una recepción (ampliada por la repercusión) que la pensada para un espectáculo a estrenar en una sala concreta por una compañía. Desde México escribió las dos comedias musicales mencionadas, Amor del bueno y Muy seor mo, y los guiones publicados La cara del villano y Recuerdo de Tijuana (1980), entre otros. Como señala Goldchluk, el hecho de que en estas producciones aparezcan figuras populares de México y su cancionero, habla de la necesidad del encuentro directo con el público que dan el teatro y el cine (2003, pp. 35-36); de la urgencia por verle el rostro a unos cuantos Valentines intermitentemente iluminados por la pantalla o la escena; del deseo, incluso, de ser él mismo un espectador fascinado de sus propias historias, que viven y se transforman más allá de su escritura. Y el extrañamiento es mayor frente a la experiencia escénica que ante la expectación bidimensional, puesto que implica la visión directa de cuerpos en acción. Ahora bien, este "sin mediaciones" que se suele destacar respecto de las voces que pueblan las novelas de Puig, así como la incorporación de registros y soportes, en el teatro toma una forma concreta. Una afirmación de tal clase no supone que en la dramaturgia de Puig no haya ambigedades (de hecho, en ella predominan universos oníricos, irreales, estilizados), sino que cuando un texto adquiere la materialidad de un espectáculo, se toman decisiones que, frecuentemente, lo vuelven más "pesado" que en el cine y la literatura (sucede con la palabra dicha, por ejemplo), o tienden a marcar una de sus varias lecturas posibles. El teatro es el más riesgoso e incierto de los medios que explora Puig, pues en escena siempre aparece algo, se pierde o sale de lo previsto: otredad potencialmente seductora para un creador que cuidaba minuciosamente lo que producía, a la vez que buscaba una salida respecto de la persecución ejercida por el gobierno peronista (su novela The Buenos Aires Affair había sido secuestrada; y se ve impedido de participar u obtener algún reconocimiento en el filme de Torre Nilsson (1974), para quien Puig escribe el guión de Boquitas Pintadas). No es casual que durante el exilio, entonces, lo teatral suba a escena en su escritura.

La primera obra escrita sin antecedente literario y vinculada a un montaje concreto es $B M E$, estrenada en su versión brasileña con el título de Quero..., con traducción de Leyla Ribeiro, en 1982, en el Teatro Ipanema de Río de Janeiro y bajo la dirección de Iván de Albuquerque. Su tercera creación dramática, Misterio del ramo de rosas $(M R R)$, se estrenó en el Donmar Warehouse de Londres en 1987. El mismo año sube a escena Gardel, uma lembrança en el Teatro de Galería, Río de Janeiro. Puig publicó en vida BME y El beso de la 
mujer araña (EBMA) (Seix Barral, Barcelona, 1983), y la traducción inglesa de MRR (trad. Alian Baker, Faber and Faber, London, 1988). Triste golondrina macho $(T G M, 1985)$ fue publicada en Italia en 1988; pero su estreno tuvo que esperar al espectáculo de Alicia Durán en la Sala Alternativa del Teatro Argentino y la Comedia de la Provincia de La Plata, en 2011. Se volvió a montar en el Teatro Regio (2013) con la dirección de Guillermo Arengo y Blas Arrese Igor, y producción del Complejo Teatral de Buenos Aires. Sin embargo, la primera obra escrita por Puig que subió efectivamente a escena fue la versión de su cuarta novela (EBMA, 1976), que se estrenó en la sala Escalante de la Diputación de Valencia, bajo la dirección de José Luis García Sánchez, en 1981. Antes de que lo hiciera el propio autor, dos compañías la habían traspuesto al teatro (una versión italiana, con autorización de Puig, y otra peruana, sin su autorización). La versión de Puig dio lugar a numerosos montajes en diversos países; y también se estrenaron transposiciones musicales en Nueva York (1990) y en Londres (1992). El relato del autor sobre la iniciativa de escribir la versión teatral a causa del disgusto provocado por las otras transposiciones, y lo que se le revela cuando ve el espectáculo, aporta algunos matices valiosos a nuestra reflexión:

Pepe [Martín] (...) me habló de la posibilidad de adaptarla al teatro y yo puse el grito en el cielo. En el ínterin, un ex director de teatro de Italia me pidió lo mismo (...). Yo recibí el libreto, la adaptación, y no me gustó. (...) Entonces hice la adaptación (...). Me di cuenta al verle en escena que ya no era yo solo, que no estaba sólo el texto allí, que había dos actores, un director, además del texto, y que las cosas que faltaban -que yo sentía como mutilaciones- estaban, a veces, más que compensadas por una mirada, un silencio, una actitud... Crecía de otra manera la historia y así fue que empecé a escribir teatro... (Capellán, 1995, p. 165).

La disconformidad con las versiones de otros se expresa como el móvil manifiesto para la práctica de transposición que ya había explorado con La cara del villano $(L C V)$, versión cinematográfica del cuento "El impostor" de Silvina Ocampo, y con El lugar sin límites (ELSL) de José Donoso. Advierte que el rodaje de Ripstein (1984) no se ciñe a su guion, y publica $C V$ para dar a conocer la escritura original:

fue un disgusto para mí ver en la pantalla mi nombre como único responsable del guión del Otro (título definitivo de $E l$ impostor), cuando habían sido introducidas, sin la menor consulta, modificaciones que desvirtuaban mi texto totalmente. (...) Pero ahora el lector puede juzgar mi trabajo directamente" (Puig, 1985, p. 7).

En otros casos, como ELSL, Puig pide que retiren su nombre de los créditos. También se manifestó insatisfecho con los desplazamientos de la película respecto del guion Pubis angelical (basado en la novela homónima de 1979). Este impulso de presencia y control por parte del autor, no es sino la contracara de la conciencia de que "no estaba sólo el texto allí" (Capellán, 1995, p. 165). El temor a la disolución del nombre (que su firma quede asociada a algo ajeno), y a que devenga -junto con su producción-ininteligible, o una absoluta confianza en la escritura ante la sospecha/seducción que le provoca la imagen viva, quedan expuestos en una anécdota que comenta acerca de Il sospetto de Maselli. Luego de la confusión que le deja la proyección, cuyo hilo narrativo no logra seguir, consigue el guion suponiendo que "escritas, esas mismas tiradas de diálogo serían más inteligibles" o se resolverían en la "relectura"; mientras que la proyección: "No se puede detener" (Puig, 1985, p. 6).

En más de una intervención recordó que el caso de EBMA fue "excepcional”, porque la novela transcurría en una celda, y esa unidad de espacio ya era teatral: "Entonces, sin yo haberlo buscado, había en la idea original una potencialidad teatral" (Capellán, 1995, p. 165). Tal mecanismo de huella ya estaba presente en el mediometraje Muestras gratis de Hollywood cosméticos (1974), que toma como punto de partida un capítulo de $L T R H$ (novela nacida de un impulso de guion) y cierra la cinta de moebius al ser pensada para televisión. No obstante, lo que el trabajo de transposición realizado por el autor $\mathrm{u}$ otros dramaturgos y guionistas pone de manifiesto, es que este no es tan directo ni sencillo, sino que frecuentemente la estructura dialogal de la narrativa de Puig, la ausencia de narrador, el espacio y tiempo acotados, y la poca cantidad de personajes, no son más que un atractivo señuelo. La progresión dramática, el trabajo con la ambigüedad, lo no dicho, y otros aspectos asociados a la hibridez de registros y desplazamientos antes descritos, requieren una cuidadosa 
elaboración de procedimientos análogos en términos escénicos. Esto mismo explica Pablo Messiez, quien dirigió en el Teatro San Martin de Bs.As (2018) la versión de Cae la noche tropical (CLNT) que él mismo elaboró junto a Santiago Loza: "Creo que gran parte de ese deseo de teatro que aparece cuando uno lee las novelas de Puig, tiene que ver con el trabajo tan sofisticado que hay con el habla cotidiana... como una especie de grabador". Pero, señala, se trata de una "aparente teatralidad"; luego se advierte que "lo que hay, como en toda gran novela, es gran literatura". Entonces primero hay que preguntarse "qué es lo esencial de ese soporte nuevo al que vamos a transponer el material". En el caso de la escena es el "espacio-tiempo", y la presencia o ausencia de los cuerpos. Así, se concentró en el trabajo con los cuerpos estáticos de las actrices Leonor Manso e Ingrid Pelicori, en un primer acto donde sólo se movían los discursos, y en el escamoteo de la presencia de la vecina (interpretada por Fernanda Orazi); en que hablaran mucho de este personaje, como en la novela, "pero que hubiera una cortina generando una tensión con ese espacio oculto"; luego tenerla a ella escuchando y producir "esa dialéctica entre lo que cuentan y lo que vemos"; finalmente, que interactúe con Nidia cuando Lucy se va a Lucerna y todas las piezas entran "literalmente en acción".

El punto de vista y la relación con el espacio determinaban, en gran medida, la cuestión central de la soledad y de la distancia, explica. El diseño escenográfico de Mariana Tirantte colocaba a las actrices en un espacio inmenso "que acrecentaba esa sensación de soledad", así como "la idea de Río y su exuberancia". En la puesta resulta muy pregnante la construcción híbrida entre el departamento y el patio de Lucy, sin paredes, donde se actualiza la tensión entre exterior e interior que recorre la novela (la sensibilidad y claridad del planteo del diseño de iluminación de Gonzalo Córdova; y el vestuario de Renata Schussheim, que imprime en los cuerpos la vivacidad de sus colores y tramas o motivos florales, terminan de configurar este sistema visual y sus efectos de sentido). Al proponerle a Messiez conversar acerca de si este continuum que contrasta con los cubículos delimitados de los otros espacios del edificio, fue una resolución también relativa a la ausencia de corte entre el pasado, el presente, el relato del otro y el propio, reflexionó que ciertamente la vegetación que entra en la casa, habla del encuentro o la mezcla entre ficción y realidad: la vida atravesando las paredes, "como entra por los relatos".

Messiez y Loza tuvieron que tomar también decisiones en cuanto a la extensión del texto. Dejaron fuera la "historia con el muchacho" para centrarse más en "la cuestión de las ficciones como creadoras de realidad" y lograr que, de alguna manera, "todos fuéramos Nidia (...) y pudiéramos caer rendidos ante la fascinación de la exuberancia del lenguaje”. Y esto tiene su correlato en un trabajo de interpretación que tuvo muy presente la idea de lo popular, sin convertirlo en un material realista, a partir de la mezcla de estilos y modos expresivos. Señala que, entre muchos otros aspectos, fue decisivo el tipo especial de relación "afectivizada" de las actrices con el público y el teatro: "me gustaba recordar a Leonor en la Boquitas pintadas de Nilsson". La textualidad a retazos y la convivencia de modos distintos de hacer avanzar la trama a partir de testimonios, documentos, grabaciones, fue para Messiez una vía de entrada al “modo Puig de contar”. Se resolvió con la lectura de cartas, o simultáneamente una actriz la enuncia mientras la otra lee en silencio, con el recurso del monólogo ante un dispositivo de grabación, o directamente la voz en off, y la conversación telefónica entre dos actrices separadas en el espacio. Si bien notamos que las (escasas) didascalias de la versión de Messiez y Loza dan cuenta de algunos procedimientos de transposición, se trata de un material para el equipo de trabajo que maneja cierta información de la puesta en escena, y no de un texto pensado para la lectura. Se agregaron "textos mínimos" para generar algún quiebre de tensión en el discurso, durante el trabajo con el espacio y la acción. Lo que sí se agregó en el trabajo con la versión escrita, "impulsado por lo que entendía de Nidia", es su relación estrecha con las plantas en ausencia de Lucy. Cada versión, cada puesta, reescribe: ese estatismo de los cuerpos en un espacio recortado y el recurso del monólogo frente a un grabador, además del universo Puig acaso remitan al teatro de Beckett, una de las estéticas que interesa especialmente a Messiez, que pronto estrena Los días felices en el Centro Dramático Nacional de Madrid.

Una de las claves para ver ese lugar complejo del texto pensado para la escena en la producción de Puig, donde efectivamente la escritura se desubjetiva y las subjetividades e intervenciones se multiplican, es lo 
didascálico: lo que no hay en sus novelas, una voz que organice, controle, indique coordenadas espaciotemporales, se anota en las didascalias. La escritura en tercera persona es la que, según ha insistido el autor, no le sale o le resulta inadecuada. En las novelas -como sucede en el teatro previo al empleo más prolífico de didascalias, el del Siglo de Oro, por ejemplo- la información de la situación, los estados, acciones, son dichos por los personajes o se desprenden de las pausas, articulaciones del diálogo, etcétera. En El beso de la mujer araña (novela), las líneas de puntos que segmentan y coordinan los fragmentos de texto indican silencios, el paso del tiempo, entre otros aspectos, de manera similar a la técnica de fundido de imágenes y ennegrecimiento de la pantalla en cine. Pero también es posible ver en esta elipsis (presente en otras novelas como en CLNT) un clásico recurso teatral: el tan conocido in medias res que ya leemos en Edipo rey de Sófocles. Otro procedimiento que puede pensarse como didascálico en la novela es el uso de varias formas tipográficas para distinguir la palabra dicha de la soñada o murmurada, los documentos, informes, diálogos telefónicos. Así, mientras que la voz narradora se ausenta, leemos allí la huella de lo didascálico, diseminado, borrado como palabra; esto es: la organización de los tiempos del diálogo, la reflexión sobre la representación y cómo dar a ver. Sería interesante además contrastar las marcas materiales que figuran en $E B M A$ (novela) con una suerte de notas didascálicas de los pretextos (apuntes metaescriturarios y listas prerredaccionales, disponibles en ARCAS), que no toman la forma de la palabra dicha sino de la glosa y el borrador, pero que tienen algún tipo de impacto productivo en el texto publicado. Ahora bien, cuando Puig escribe teatro o versiona sus novelas, junto a las mencionadas modalidades poéticas, da paso también a las didascalias tradicionales cuya inscripción explicita aquello que no resultaba necesario aclarar en su narrativa y que justamente por ello, entre otras singularidades, se la ha considerado experimental. Pareciera que sus novelas recuperan, como afirma Dubatti, algo de la experiencia teatral, antes que de la tradición dramatúrgica: "la singular estructura dramática que Puig descubre "dentro" de la novela" (Puig, 2011, p. 11). Por un lado, recapitulando, observamos la huella de lo teatral en sus novelas (la reflexión sobre el dar a ver y escuchar), que no se presenta como didascalia-voz narradora o comentario, y que se anuncia además en los manuscritos prerredaccionales y redaccionales por medio de notas y recordatorios para el proceso de composición o corrección. Y, por otro, la presencia textual de esa voz en las didascalias de sus obras teatrales, musicales, y guiones. Escritura que, a la vez, no será dicha en escena, apenas leída, y por eso insiste en inscribirse: "En términos de recompensas: un libro, incluso un manuscrito, se llega a leer, pero si una obra de teatro o una película no es producida, es como si no hubiera pasado nada" (Puig, 1985, p. 5). En lo más íntimo del lamento y del goce, sabe que lo didascálico es lo éxtimo del borrador u "otro del texto" (Lois, 2001, p. 18).

\section{3. "UNA CORTINA IRREAL PERO NO TRASLÚCIDA CAE"}

Goldchluk (1998) señala algo a propósito de las didascalias de la comedia musical Muy señor mío, que sugiere la irrupción de lo poético ya en la primera obra escrita para la escena, en lugar de didascalias del tipo instructivo. Estas definen al personaje de Chicharrona, caracterizado por su teatralidad desde la imitación y el travestismo, como “...una mujer ultrarreceptiva, que a cada estímulo responde de manera acorde, es decir que si se la trata como bella se sentirá bella y actuará como bella, si se la trata como comedia y será el principal resorte cómico del personaje" (p. 5). El procedimiento de la parodia está presente "tanto en la modificación de las letras de las canciones que intervienen en la trama, como en las acotaciones escénicas, donde se indica que la música debe detenerse a destiempo, o acelerarse cuando la historia lo requiere” (p. 5). Si bien las didascalias que se registran en los pretextos y en la versión publicada de EBMA para teatro son más tradicionales -en términos teatrales- que las de la pieza antes descrita (es decir, que plantean algo acerca de la materialidad de la escena), conviven con modulaciones literarias (más destinadas a la lectura que a una mesa de trabajo del equipo del espectáculo); o bien lo técnico es llevado a las orillas del relato: "Oscuridad total. De pronto caen luces blancas sobre las cabezas de dos hombres (...)” (Puig, 2011, p. 21). Aunque aquí se esté sugiriendo el modo en que debería verse, no dice "se ilumina", "se encienden cenitales a cuchilla" sino 
un narrativo "De pronto caen". Pero un realizador atento a los procedimientos, comprenderá que más que una indicación de luz que hay que respetar o no, lo que sí conviene atender en, por ejemplo, "La luz blanca que sólo iluminaba las cabezas pasa a iluminar la figura entera de ambos; por primera vez se ve la celda" (p. 22), es que allí se recupera un mecanismo central de la novela: la configuración de la intriga, ese ir revelando la situación de a poco, en este caso, para el espectador. El director puede encontrar distintas resoluciones, ya sea con la luz u otro recurso de la escena, para materializarla. Otras didascalias señalan aspectos de carácter, estados de los personajes, y acciones pensadas para la escena: "Sin humor" (p. 24), "Acumulando rabia" (p. 25). Todo eso que no se describe en la novela se explicita en las didascalias-comentario; varias agregadas en lapicera sobre un dactiloescrito (pretexto redaccional completo en ARCAS). El procedimiento se reitera en el guion de Schreder para la película dirigida por Héctor Babenco que Puig corrige el mismo año (EBMA, ID puig.GEbma.G.N.15.0128_(1)), pero con algunas inscripciones más técnicas del tipo: "Fade up". Este gesto se esclarece si se considera que Puig lo modificó durante el rodaje y en contacto directo con la producción. No menos interesante es la mezcla de tramos en español y en inglés, en la versión del guion propuesta por Puig que no había sido aceptada- posteriormente (1983). La concomitancia cronológica de la producción de las versiones se evidencia en el cruce o la irrupción de formas no esperadas para un género y otro. Por mencionar alguna anotación característica del guion de cine en la versión para teatro: "Día, Valentín acostado..." (p. 38); "Luz correspondiente a día..." (p. 42). A la vez, encontramos notas que expresan la búsqueda de palabras para aproximarse a lo que se "ve": "menos comunicativo aun que de costumbre, sombrío"; "ácido, nada sentimental” (p. 27); "resignándose, en tono de madre de clase media” (p. 38). Otras rarezas para la tradición dramatúrgica son, por ejemplo, didascalias que explican el modo en que se articula algo que ya se presentó en el texto, cuando lo más frecuente es que se indique inmediatamente antes: "A continuación se oye una conversación, grabada como también lo fue la Voz del Guardia, mientras en escena queda Valentín" (p. 44), "Llegado este momento Molina ya ha entrado de vuelta a la celda, va sacando los víveres..." (p. 56). La ambivalencia queda clara en el hecho de que los nombres de los personajes antes de la réplica aparecen en la versión publicada (quizá por el peso de la tradición dramatúrgica, expresado también en “...cae el telón” (p. 69)) pero no en el redaccional completo que aún sigue la lógica de la novela, donde esas "didascalias" están ausentes. Esto se confirma al contrastarlo con los prerredaccionales de Triste golondrina macho, escrita como texto dramático, en cuyas páginas nombra a los personajes antes de cada réplica. Las didascalias de este último texto, más que indicar aspectos de puesta en escena, activan la imaginación y la experiencia de lectura ante el relato popular:

Modesta pero acogedora cabaña, con profusión de detalles femeninos. Podría ser la casa de la abuela de Caperucita Roja. Estamos a comienzos del siglo XIX, en tierras frías (...). Escenario, iluminación y actuación deberían crear una atmósfera de cuento de hadas (Puig, 2011, p. 157).

Además de la evidente indeterminación y digresión poética, en el marco de la extrañeza general de la obra, resulta curioso que entre el acto I y II se señale que permanece todo igual para retomar ahí mismo la acción. Se identifica aquí la visión de un espectador que observa el final del acto y vuelve a encontrar la escena cuando se abre el telón, luego de un intervalo, antes que una convención dramatúrgica: "El mismo escenario. Los tres personajes están en la misma posición, es decir la Hermana Menor desmayada” (p. 179). Pero hay todavía una nota más singular donde podemos leer una reflexión sobre los procedimientos de representación: “...y una cortina irreal pero no traslúcida cae, ocultando de la vista del Pastor de Cabras -y del público- la acción que sigue" (p. 189). Aquí repone un recurso muy empleado en comedias y tragedias clásicas (la cortina que oculta una escena para los personajes pero que el espectador ve o conoce), y lo desarticula al aclarar que esa cortina inexistente no sólo se interpone ante los ojos de los personajes sino también del público; es decir, al poner en entredicho los bordes de la ficción con esta figura imposible que está más próxima al conocido verso de Juan Gelman sobre la poesía, "un árbol sin hojas que da sombra”, que a una dirección escénica. Esto conduce a representarnos un Puig no capturado por el Teatro (con mayúscula), ni en un contacto tan estrecho 
con la realización escénica y la práctica dramatúrgica, sino que mantiene una relación amorosa intermitente con el poder de lo teatral para crear realidades imaginarias. Arrese Igor comenta que en la puesta de 2013 radicalizaron tal estilización, y que fue preciso atender a los dos posibles finales que proponen sus didascalias, pues: "como creadores, la indeterminación de su escritura, el malentendido, lo que no está regado de luz, nos viene bárbaro para tejer pliegues de sentidos" ${ }^{6}$

Leer los prerredaccionales de $B M E$, es prácticamente leer una novela. Además de que en el dactiloescrito completo las didascalias son numerosas y notablemente narrativas, es la zona del texto que más se modifica (en lapicera) y llega a la versión publicada. Basta citar la primera de ellas para advertir, como ya observamos, la futilidad de las lecturas pragmáticas:

Amplio recinto que reúne sala de estar y comedor en una lujosa casa de campo. El estilo es post-art-nouveau y pre-art-déco. Corre el año 1948. Es de tarde, la luz solar todavía no ha empezado a declinar. Los dueños de casa se encuentran sentados en la sala, la edad es indeterminada, se diría que unos cincuenta años. Son elegantes, mas de una manera extremadamente sobria y opaca, como si se los viera a través de un velo gris. Llama la atención especialmente que ella no se haya teñido las canas. (...) Nada es realista, todo es estilizado (Puig, 2011, p. 73).

En este texto la voz también bascula entre una que conoce a los personajes ("paulatinamente recupera la flema y el aire de superioridad que le son habituales y, tras los cuales, oculta siempre sus verdaderos sentimientos" (p. 73)), y otra que vacila o no está del todo segura respecto de lo que se debería encuadrar. Esta última parece ubicarse en el sitio de un espectador testigo de cómo se compone la escena, y no en una visión demiúrgica o en la figura del director: "Se acerca a la Dueña, tal vez fingiendo reconocerla" (p. 79). Tal punto de vista puede tener su correlato en el rol que toma Puig dentro de la actividad cinematográfica, no identificado con la "autoridad" del director-realizador, sino la de un guionista que imagina (Goldchluk, 1996, p.474). Por otra parte, si bien la didascalia inicial de $M R R$ es similar a las de $B M E$ y $T G M$, en ella sí se tiende a modular la aclaración de una manera más didáctica que en las otras dos, posiblemente por tratarse de una estética próxima al drama moderno realista (con cierto aire expresionista, según Dubatti (Puig, 2011, p.13)). Así, se describe una suerte de guion de luces que distingue el carácter espectral de las escenas de alucinación, del regreso a la realidad. Cuando la Enfermera sale del armario representando la visión de la Paciente, que proyecta en ella la imagen de su hermana, se anota la "luz espectral" y la "luz realista".

Las numerosas didascalias del musical Un espia en mi corazón, escrita en 1988 para un proyecto pensado para el grupo Caviar y la diseñadora de vestuario y artista plástica argentina Renata Schussheim, funcionan como una suerte de bisagra entre los universos y citas superpuestas (apropiación de géneros populares del espectáculo argentino, procedimientos del melodrama, radioteatro, sainete, revista porteña, comedia blanca del cine nacional). Algunas sugieren modos, tonos y registros para ciertas réplicas, como lo haría Libertad Lamarque, Carlos Gardel, Mirtha Legrand. La clave está en el "como si”, "tipo", “a lo": "interrumpe, con voz nasal tipo "Niña de Haedo"” (Puig, 2011, p.199-200); "VOZ DE LOCUTOR: (el de la radio El Mundo de los 40 era arquetípico)" (p. 201); “Van surgiendo perfiles de un tétrico laboratorio a lo Dr. Frankenstein" (p. 202). De nuevo se advierte esa mirada del espectador que cuenta lo que recuerda, ve o imagina (el conocido inicio de $E B M A$ : "A ella se le ve que algo raro tiene"): "La dueña está como pegada a la máquina de coser. Aparenta unos treinta y cinco años (...). Se la ve melancólica” (p. 204). Los datos mínimos para situar la acción presente son siempre excedidos por una modalidad afectiva. Esto es claro con la mención "un abuelo", en una didascalia (p. 199), y la referencia “abuelito”, en otra (p. 200); o con la abundancia de expresiones hiperbólicas ("Grandote, bigotazos” (p. 208); “por todas partes” (p. 210)). A la vez se anota algo de la posible materialidad de la escena en términos más técnicos ("proscenio", "decorado", "sombras", etcétera), donde se pueden leer incluso marcas del sistema teatral contemporáneo: "(Comienzan proyecciones de incendios, estilizados motivos arquitectónicos nazimperiales)” (p. 199). La incorporación de proyecciones cinematográficas o de diapositivas ya era conocida para el teatro argentino de entonces, aunque probablemente a Puig le haya resultado más familiar el empleo que se hacía de la misma en el teatro y la comedia musical norteamericanos. 
En palabras de Szuchmacher, en torno de estas cuestiones: "Dime con quién hablas y te diré qué didascalias escribes". 7

Las didascalias de los guiones de Puig también dan cuenta de un impulso narrativo aunque suelen enfocarse más en situar la acción, describir flashback y cómo se articulan las escenas, las voces en off, superposiciones de imágenes, el carácter o estado de un personaje. No obstante es interesante atender guiones de los años 60, cuya escritura está más cerca de la novela, o el relato breve, y del teatro, que del guion cinematográfico. Verano entre paredes (1959) (Amícola, 1996) se destaca por sus didascalias extensísimas y sumamente narrativas, entre réplicas, en las que no faltan figuras poéticas y verbos en pasado. Frente al típico presente en grado cero o el uso potencial de las didascalias, aquí nos topamos con una combinación -no teatral ni cinematográfica- del pretérito imperfecto, perfecto simple y compuesto. A la vez, incorpora las didascalias tradicionales de la dramaturgia al interior de la réplica (entre paréntesis, luego del nombre o de la frase, en presente). Tampoco en La tajada (1960) (Amícola, 1996) se leen notas técnicas -a excepción de un clásico "Noche"-; sino el relato de quien enuncia a medida que el ojo registra lo que acontece, antes que el de quien indica cómo debe componerse una escena, tal como se lee en esa tercera persona de Boquitas pintadas (novela). Las didascalias del guion filmado con Raúl de la Torre en 1982, Pubis angelical, además de presentar ambigüedades poéticas, sugiere lo que podría verse y oírse. Esto probablemente se deba a que el autor lo escribió a pedido de una producción específica: huella o germen del diálogo entre escritura y realización. Sin embargo, las digresiones narrativas predominan sobre cualquier carácter técnico: "MARIDO (la ama pero sabe que tiene que obedecer)" (Puig, 2004, p. 54). Este brevísimo muestreo acaso arroja una sospecha sobre las diversas direcciones que toman las distintas versiones de sus materiales literarios, que sería relevante estudiar desde los saberes específicos de la puesta en escena y la realización cinematográfica. Lo que sin duda queda expuesto con tal repertorio de casos es que la figura de lo didascálico, en la producción de Puig, condensa tanto lo poético como lo explicativo y controlador de una inscripción que se sabe perdida.

En líneas generales no se escriben ni se publican guiones después de rodar la película (tampoco se suelen publicar guiones que nunca se filmaron), sencillamente porque no se vuelve a ese texto, además de que esta no se transforma con las sucesivas proyecciones. He aquí una de las grandes diferencias respecto del texto teatral, que siempre es posible material de interpretación para otra realización, y frecuentemente se reescribe en el proceso de ensayos, o luego de estrenada la obra, en versiones especialmente preparadas para una edición. Si bien los guiones del autor que nos ocupa, y especialmente sus didascalias, postulan algo que se va a realizar en otros medios no lingüísticos, notamos que no lo formulan en el lenguaje específico de este tipo de escritura dirigida a lectores especializados, sino una más próxima al lector de teatro y de literatura. Una vez más el autor ejerce algún tipo de desvío en un género o práctica, donde lo que importa-siempre- es la composición de la voz/las voces.

\section{De contagios y AFEcciones}

Las modulaciones de las didascalias que hemos descrito destacan eso que resta pero que de algún modo se manifiesta: tanto el deseo de control sobre la creación, de la presencia (intermitente pero constante) de una instancia de narración, como la conservación o difusión de su valor literario más allá de la realización teatral o cinematográfica. Sería interesante elaborar un análisis completo y riguroso de sus didascalias. Aquí apenas se enuncia el carácter singular de esta zona de la escritura del autor donde se observa la huella de lo teatral: eso que siempre está por hacerse y se mantiene en el terreno tan incierto como poético de la transposición/ traducción. Perogrullo: una lectura sobre esta escritura no puede sino evocar diversas voces, géneros y formatos. Para realizar este estudio se trabajó con archivos (manuscritos, registros audiovisuales de puestas, fotografías), se entrevistó y conversó con figuras relevantes para el caso, se grabó, se transcribió. De contagios y afecciones sabe el amor: un procedimiento de composición, una poética de la expectación, modos de hacer y de dar a ver, escuchar, y leer, que Puig no buscó... porque estaban desde siempre. 


\section{REFERENCIAS}

Amícola, J. (Comp.). (1996). Materiales iniciales para La traición de Rita Hayworth, (469-480). La Plata, Argentina: Centro de Estudios de Teoría y Crítica Literaria.

Barthes, R. (2008). El placer de texto y Lección inaugural. Buenos Aires, Argentina: Siglo Veintiuno.

Carera, D. (2016). Las lenguas vivas. Zonas de exilio y traducción en Manuel Puig. Buenos Aires, Argentina: Prometeo Capellán, J. A. (1995). El teatro de Manuel Puig. Teatro: revista de estudios teatrales (6-7), 163-176.

Derrida, J., et al, (2013 [1995]). Archivo y borrador. En G. Goldchluk y M. Pené (comp.), Palabras de archivo (207-235). Santa Fe, Argentina: Editorial de la Universidad Nacional del Litoral.

Giordano, A. (1996). Manuel Puig: Los comienzos de una literatura menor. Orbis Tertius, 1(2-3), 255-274.

Goldchluk, G. (1996). El gran imaginador. En J. Amícola (Comp.), Materiales iniciales para La traición de Rita Hayworth, (469-480). La Plata, Argentina: Centro de Estudios de Teoría y Crítica Literaria.

Goldchluk, G. (1998). A través de las fronteras: (Exilio, identidad y escritura en textos mexicanos de Manuel Puig). Orbis Tertius, 3(6), 89-97.

Goldchluk, G. (2003). Intertextualidad y génesis en los textos mexicanos de Manuel Puig: Novelas, guiones, comedias musicales (1974-1978) (Tesis de posgrado). Recuperado de http://www.memoria.fahce.unlp.edu.ar/tesis/te.15 7/te.157.pdf

Lois, E. (2001). Génesis de escritura y estudios culturales. Buenos Aires, Argentina: Edicial.

Monteleone, J. (1987). El teatro de Ricardo Monti. Teatro del Pueblo. Recuperado de http://www.teatrodelpueblo.o rg.ar/dramaturgia/monteleone001.htm

Mora, G. (1988). Un problema de la pragmática del texto teatral: El nivel del acotador en Bajo un manto de estrellas de Manuel Puig. Dispositio: Revista Hispánica de Semiótica Literaria, 11(33-35), 223-233.

Puig, M. (1985). Prólogo a La cara del villano/Recuerdos de Tijuana. Barcelona, España: Seix Barral.

Puig, M. (2004). Los 7 pecados tropicales y otros guiones. Buenos Aires, Argentina: El Cuenco del Plata.

Puig, M. (2011). Teatro reunido. Buenos Aires, Argentina: Entropía.

Rasic, E. y Calvente, P. (2017). Álbum Puig. La Plata, Argentina: Malisia)

Szuchmacher, R. (2015). Lo incapturable. Puesta en escena y dirección teatral. Buenos Aires, Argentina: Reservoir Books.

\section{Notas}

1 El número de páginas corresponde al dactiloescrito de los guiones La cara del villano y Recuerdo de Tijuana, con prólogo del autor, que pertenece al Archivo Puig disponible en ARCAS.

2 Ver Rasic (2017).

3 Ver Cabrera (2016).

4 Por mencionar un caso: Puig agregó una escena a Bajo un manto de estrellas luego de su estreno. Este trabajo de reescritura condujo a algunos realizadores a consultar el archivo del autor para el proyecto de puesta en escena, según nos comenta Goldchluk.

5 Esta versión inédita fue generosamente facilitada por Messiez para realizar nuestro estudio. Asimismo el registro audiovisual de función fue muy gentilmente brindado por Federico Lucini Monti (Complejo Teatral de Buenos Aires). La Entrevista inédita realizada al director que aquí se cita será publicada en su versión completa en la Revista del Congreso en homenaje al autor. A propósito de la transposición de esta novela, Goldchluk comenta que en los años dedicados al trabajo con el archivo, supo de un proyecto de película que sería protagonizado por Sofía Loren y de los avances para una puesta en Buenos Aires con Carmen Maura, que finalmente no prosperó.

6 Conversación con el dramaturgo, intérprete, director, y docente argentino Blas Arrese Igor para la elaboración de este artículo, grabada y transcripta.

7 Conversación mantenida con el dramaturgo, intérprete, director, y docente argentino, a propósito de este estudio. 